\title{
Development and perspectives of latin american women in urology
}

\section{Desarrollo y perspectivas de las mujeres latinoamericanas en urología}

\author{
Ana María Autran-Gómez, ${ }^{1}$ Alejandro Rodríguez. ${ }^{2}$
}

Over the last 20 years, the proportion of female urologists has slowly but steadily increased. The overall percentage of women participating in medical residency programs in the USA increased by $22 \%$ during 1980 and $43 \%$ in 2010 ( $^{(1)}$ The proportion of women in various specialties continues to vary. Previous studies looking at women urologists in the USA have found differences in demographics and practice trends, between female and male urologists, that may have important implications. In 2013, Pruthi et al. reported on the trends of the urologic workforce. ${ }^{(2)}$

They performed a database search and reported basic demographic data and practice patterns of the current urologic workforce in the United States. They found that in 2009 , the average age of practicing urologists was 52.5 yrs., with $40 \%$ of the workforce being $>50$, making urology the second oldest surgical subspecialty. Long standing gender disparities exist in urology. In 1995, in the USA, women comprised $1.2 \%$ of boardcertified urologists, in $2017,8.8 \%$ of all urologists and $21 \%$ of urologists under 45 years of age were women. ${ }^{(3)}$ The proportion of women in urology is increasing, but, in comparison to men, women in urology are still underrepresented. In leadership positions, they have not achieved similar promotion progress, and are paid less in comparison to men.

In Latin America, over the last 10 years, the involvement of women in urology has increased exponentially. We are currently carrying out a general urologic consensus with the participation of the 23 member countries of the Confederación Americana de Urología (CAU), with the aim of identifying and characterizing the current workforce of women urologists in our countries. The CAU recently opened a new gender office called Oficina de la Mujer Uróloga (Women Urologist Office), in October 2021. This new office will allow the development of different programs to promote the training, leadership, and active participation of women urologists in the different areas of surgical, clinical, and research experience.

${ }^{1}$ Confederación Americana de Urología, Oficina de Investigación, Buenos Aires, Argentina.

${ }^{2}$ Confederación Americana de Urología, Secretaría General, Buenos Aires, Argentina. 


\section{Development and perspectives of latin american women in urology. Autran-Gómez A. M., et al.}

For this reason, the Confederacion Americana de Urología, in collaboration with the Sociedad Mexicana de Urología and Revista Mexicana de Urología, has created this special issue, to announce the clinical, surgical and research activity of Latin American women urologists, and continue promoting the different projects that foster the growth of the great urologic Latin American community.

\section{References}

1. Grimsby GM, Wolter CE. The journey of women in urology: the perspective of a female urology resident. Urology. 2013 Jan;81(1):3-6. doi: https://doi.org/10.1016/j.urology.2012.07.050

2. Pruthi RS, Neuwahl S, Nielsen ME, Fraher E. Recent Trends in the Urology Workforce in the United States. Urology. 2013 Nov 1;82(5):987-94. doi: https://doi.org/10.1016/j. urology.2013.04.080

3. AUA. The State of the Urology Workforce and Practice in the United States 2014. USA: American Urological Association; 2014. 